\title{
Comparative physico-chemical evaluation of soymilk and soya cake produced by three different methods.
}

\author{
Onuorah, C. E., *Adejare, A. O. and Uhiara N. S. \\ Department of Food Science and Technology, \\ Federal Polytechnic, Bauchi \\ P. M. B. 0231, Bauchi, Nigeria \\ *Address for correspondence
}

ABSTRACT

\begin{abstract}
Soymilk and soyacake were produced by three methods: illinois, (A), cornel (B), and traditional oriental (C). Physiochemical, microbiological, and sensory properties were evaluated. Method $\mathrm{C}$ had the highest soymilk yield of $57.76 \%$ followed by B with $55.17 \%$ and A $52.85 \%$. The protein contents of soymilk were $2.8,3.5$, and $3.8 \%$ respectively for methods $\mathrm{A}, \mathrm{B}$, and $\mathrm{C}$. The protein contents of the respective soyacake were $6.6,6.69$, and $8.0 \%$ for $\mathrm{A}$, $\mathrm{B}$, and $\mathrm{C}$ respectively. The fat contents of soymilk were $2.35,2.22$, and $2.18 \%$ for $\mathrm{A}, \mathrm{B}$, and $\mathrm{C}$ respectively; while soyacakes were $4.50,4.50$, and $4.38 \%$ for $\mathrm{A}, \mathrm{B}$, and C respectively. The ash contents of soymilk were $0.40,0.42$,
\end{abstract}

and $0.45 \%$ or A, B, and C respectively; soya cake recorded higher figures of $0.81,0.79$, and $0.79 \%$ for samples $\mathrm{A}, \mathrm{B}$, and $C$ respectively. Raw and pasteurized soymilk stored at $4^{\circ} \mathrm{C}$ kept for 3 and 7 days respectively. The microbial loads of the raw soymilk were $3 \times 10^{5}, 4 \times 10^{5}$ and $7 \times 10^{5} \mathrm{Cfu} / \mathrm{ml}$ for $\mathrm{A}, \mathrm{B}$, and $\mathrm{C}$ respectively. There was no growth for the pasteurized samples. Sensory evaluation of soymilk indicated that sample A was preferred to B, while $\mathrm{C}$ was least preferred.

Keywords: soymilk, soya cake, processing, physicochamical evaluation

\section{INTRODUCTION}

$\mathrm{S}$ oymilk is a fine emulsion of soybean flour or water extract of wet ground soybean. Soymilk looks like dairy milk except that it has its own peculiar odour and taste. According to Wang, et al., (1978), soymilk originated in the Orient by a Chinese Philosopher. This has since spread to many parts of the world especially the so-called "third" world, although it is still more popular in Asia than any other parts of the world. In view of the continued dairy milk shortage or absence in the developing countries, there is a need for increased production of soymilk. Soymilk is easy and cheap to prepare. The raw material soybean can also grow in many parts of the world all seasons. Cultivation of soybean is relatively easier and cheaper than production of dairy cattle.
Soybean (Glycine max merrill) belongs to the family Leguminosae. It is native to China and is one of the oldest world crops. Even though soybean is native to China, it is now widely grown in both tropical and temperate regions of the world. The world leading producer of soybean is United States followed by China (Wang, et. al., 1978).

The total production in Nigeria is very insignificant in the world market. However, with the advent of renewed interest in Agriculture, there is bound to be an increase in soybean production. The major areas of soybean production in Nigeria are Benue, Bauchi, Plateau, Borno and Kaduna States. There are many varieties of soybean. The shape and size of seeds vary fromsmall round pea to large elongated beans, 
the colour; also vary from yellow, brown, green to black. The seeds are enclosed in a short hairy pod containing 2-3 seeds attached to the plant.

Soybean is very rich in protein and oil. Soybean is one of the commercial sources of vegetable oil. Soybean on dry weight basis contains about $40 \%$ protein, $21 \%$ oil, $34 \%$ carbohydrate and $4.9 \%$ ash. The amino acids distribution of soybean is close to that recommended by Food and Agricultural Organization (FAO) of United Nations for human nutrition in terms of essential and non essential amino acids (Nwanekesi; 1984). However, soybean is deficient in sulphur containing amino acids.

Soybean is also known to contain anti nutritional and flatus factors, beany flavour, disagreeable taste and cooking difficulty. Some anti nutritional factors in soybean such as trypsin inhibitors, hemaglutinings, lipozygenease are relatively sensitive to heat. Phytic acid (which interferes with availability of calcium), oligosaccharides including raffinose and stachyose (which are the causative factors for flatulence and uncomfortable feeling often experienced upon ingestion of soybean products) are not effectively destroyed by processing heat. The undesirable beany flavour of the bitterness of soymilk can be eliminated by cooking in an aqueous sodium bicarbonate at a temperature of about $80^{\circ} \mathrm{C}$ followed by extraction of protein and other water-soluble components (Nwanekesi, 1984). The composition of soymilk varies with the varieties of soybean used and the method of production (Wang, et al., 1978).

Several processes have been adopted in the production of soymilk. The processing method varies from one place to other. The most common method of soymilk production is the Traditional Oriental method in which soybean is soaked overnight, crushed wet and sieved to get soymilk. Johnson and Snyder (1978) described two other methods of processing termed Illinois and Cornell methods. These methods were aimed at improving the acceptability of soymilk in terms of odour, and flavour. There are other various methods reported by Omotaye, (1984), and Wang, et al., (1978). Some of these methods include full fat soy-flour process, protein isolate process, and water emulsion process. Upon heat treatment and some chemical treatments, these undesirable characteristics of soybean are either eliminated or reduced.

This study is aimed at producing soymilk and cake by three different methods and evaluating the soymilk and cake, to determine the best of the methods in terms of yield, chemical and sensory qualities for human acceptance of the products. To determine the shelf life of pasteurized and unpasteurized soymilk.

\section{MATERIALS AND METHODS Materials}

Soybean of light brown and green varieties were purchased from Bauchi Muda Lawal market.

\section{Preparation of soymilk}

Three different methods described by Johnson and Snyder (1978) were used in soymilk production. The methods include Illinois, Cornel, and Traditional Chinese. Soymilk was produced from both light brown and green soybean varieties. For each method, $200 \mathrm{~g}$ of soybean was used. Two litres of water was used to soak soybean for Cornel and Traditional methods while $0.5 \% \mathrm{NaHCO}_{3}$ in two litres were used in soaking for Illinois process. All the samples were soaked for $28 \mathrm{~h}$ and then decoated and rinsed with tap water. Sample A (Illinois method) was blanched using a solution of $0.5 \% \mathrm{NaHCO}_{3}$ for 30 min at $100^{\circ} \mathrm{C}$. The beans were wet milled with 1:41itres of water. The soymilk was obtained by passing the slurry through $0.4 \mathrm{~mm}$ screen followed by pasteurization at $68^{\circ} \mathrm{C}$ for $30 \mathrm{~min}$.

\section{Determination of soymilk yield}

The percentage yield for soymilk from the three methods was determined by weighing the soybean slurry obtained immediately after wet milling and the soymilk obtained after sieving.

$$
\% \text { Yield }=\frac{\text { Mass of soymilk x } 100}{\text { Mass of slurry }}
$$




\section{Determination of chemical components:}

Moisture, fat and Ash contents of soymilk and Soyacake Moisture were determined by method described by Pearson (1981). Protein was determined by Kjedahl method as described in (AOAC, 1980).

\section{Physical characteristics}

Linthers Polarimetric described by Joslyn (1971) was used for determination of total solids in soymilk and Soyacake and $\mathrm{pH}$ was determined using pH meter model Minisis 600.

\section{Microbial examination}

The methods described by Speck, (1976), were used for aerobic and psychotropic counts for raw and pasteurized soymilk. Raw milk samples were taken after production while pasteurized soymilk samples were taken after pasteurization. Both were kept at $5^{\circ} \mathrm{C}$ for subsequent tests, during shelf-life studies. Proteolytic test of isolated microorganisms and Coagulase tests from raw soymilk was tested as described by Carpenter (1977). A shelf life study on raw and pasteurized soymilk was done. All samples were examined for microbiological changes after one week of storage and continued until the soymilk is unfit for human consumption.

\section{Sensory evaluation of soymilk}

Evaluation was done by 20 judges selected randomly from Polytechnic Community. The nine (9) point hedonic scale was used. The characteristics evaluated, were appearance, flavour, after taste, and overall acceptability. The responses were statistically analyzed via analysis of variance.

\section{RESULTS AND DISCUSSION}

Soymilk yields, total solids and refractive Index were determined and the results are shown in Table 1.Soybean seeds used for milk production, soymilk, and soyacake were analyzed and the result shown in Table 2. Mean scores of the sensory evaluation on 9-point hedonic scale of soymilk samples from different production methods are shown in Table 5.
The protein of soybean used for the production is comparable to the results obtained by Shurpalekars (1967), but lower than that recorded by Desrosier (1977) and the differences could be attributed to the variety of the soybean used. The ash and moisture content agreed with the work of Nwankesi (1984). All the variables could be attributed to the variety of the soybean used.

The ratio of soybean to water in all preparations was 1:7. Sample A recorded the lowest yield of $52.85 \%$ while sample $\mathrm{C}$ recorded the highest yield of $57.76 \%$ and sample B recorded $55.17 \%$. These values were comparable to $53.1 \%$ for sample A and $58.7 \%$ for sample C as reported by Johnson and Snyder (1978), although the ratio of soybean to water was 1:8. The lower yield reported for sample A might be due to the higher heat treatment. Also, from Table 1, both total solids and refractive index which measures the amount of total soluble solids showed a decline from sample $\mathrm{C}$ to A. Johnson and Snyder (1978), noted that heating of soybean before grinding partially coagulates protein and keeps the protein bodies intact when soybean is disrupted and this results in retention of more solids on the screen.

The ash content (Table 2) for all samples were close to the figures reported by Omotoye (1984). Soyacake contained more ash soymilk even though there is a higher ratio of soluble salts than insoluble in soybean. The higher ash content of the cake could then be due to the particle size of ground soybean before sieving. The finer the flour, the more endosperm is exposed hence more mineral will be extracted in soymilk.

The moisture content of soymilk and cake shown in Table 2. Moisture content of soymilk samples A, B, and C were $89.2 \%, 88.8 \%$, and $87.0 \%$ respectively. These values are comparable to $90.5 \%$ and $92.5 \%$ for traditional (C) and illinois (A) methods reported by Wilkens, et al, (1967) [although the soybean/water ratio was 1:8 compared to 1:7 used in this study]. The moisture content of soyacake of $30.10 \%, 29.80 \%$, and $29.40 \%$ for A, 
$\mathrm{B}$, and $\mathrm{C}$ respectively. The higher moisture content of sample A could be as a result of higher heat treatment, which could have led to partial coagulation of protein and restrict more water expulsions from the cake.

Sample A had least protein $2.5 \%$, while $\mathrm{C}$ had the highest $(3.8 \%)$ and $\mathrm{B}$ had $3.5 \%$. The value for sample $\mathrm{B}$ and $\mathrm{C}$ are very close to the value reported by Wilkens, et. al., (1967), 3.5\% and 3.7\% for Band C. Sample A's low protein may be due to the higher heat treatment it received which might have denatured some protein. The soyacake protein showed similar trend as in soymilk.

The carbohydrate content of soymilk was similar to that reported by Wilkens, et al, (1967), $2.69 \%, 2.73 \%$, and $2.80 \%$ compared with $2.40 \%$, $2.57 \%$, and $2.62 \%$ for samples A, B, and C respectively. The slight difference could be due to the variety of the raw material. The soyacake had higher carbohydrate content than soymilk, this could be due to size reduction i.e., if not finely ground, and the oligosaccharides (which are not very soluble) would be retained in the sieve - i.e. in the cake.

The fat content of soymilk and soycake is shown on table 2. The soymilk samples contained $2.35 \%$, $2.22 \%$, and $2.18 \%$ for A, Band C respectively; these figures were comparable to those obtained by Babajide (1985), (2.28\%, 2.23\%, and $2.12 \%$ for Illinois (A), Cornel (B) and Traditional (C) methods respectively. Here sample $A$ had the highest and $\mathrm{C}$ the lowest. This is due to the fact that heat aids extraction of oil. In addition, there was more fat in soyacake than soymilk because of the less solubility of oil in water.

The $\mathrm{pH}$ of soymilk shown in Table 2, showed that sample A is close to neutrality (7.02) while Band $\mathrm{C}$ were slightly acidic $(5.4 \%$, and $5.38 \%$ ).

This is due to the use of $\mathrm{NaHCO}_{3}$ for both soaking and blanching of sample $\mathrm{A}$. The $\mathrm{pH}$ of $\mathrm{B}$ and $\mathrm{C}$ were slightly lower than the $\mathrm{pH}$ of normal cow's milk.
The results of microbial examination of soymilk (raw and pasteurized) were shown on table 3 , and 4 below. The result of total plate count is shown on table 3. The highest microbial load was found in sample C $\left(7.10 \times 10^{5} \mathrm{Cfu} / \mathrm{ml}\right)$, while sample A had the least $\left(3.10 \times 10^{5} \mathrm{Cfu} / \mathrm{ml}\right)$. The slight difference was due to the facts that sample A, heat and $\mathrm{NaHCO}_{3}$ were employed which was not the case in C. The absence of microorganisms in pasteurized sample showed that the pasteurization time and temperature $68^{\circ} \mathrm{C}$ and 30 min were adequate.

Further biochemical test on raw soymilk (Table 4) showed that the microorganisms in the raw soymilk were proteolytic and not psychrophilic, not coagulase positive. This indicated that the microorganisms may not be pathogenic, but may induce spoilage.

Table 5 showed consumer rating of soymilk samples for appearance, flavour, after taste and overall acceptability. Sample A was most acceptable for all qualities evaluated. More than $75 \%$ of the judges indicated that sample A was very creamy, bland taste, no odour and no crystal like solids. Sample B had slight beany flavour, taste, and odour; felt crystal like substances and little after taste. Sample C according to more than $50 \%$ of the judges, contained more solids, had characteristic strong beany odour, taste and very long after taste. The preference of sample A indicated that $\mathrm{NaHCO}_{3}$ not only had effect of softening the soybean, but also had removed the beany odour and left the soymilk with bland and odour free.

In shelf life studies, samples A and B remained stable emulsion for both raw and pasteurized samples, while there was separation in sample $\mathrm{C}$ both raw and pasteurized. The beany odour of raw soymilk (C) became stronger the second day of storage at $4^{\circ} \mathrm{C}$. It had also salty taste. By the fifth day of storage, the odour of samples B and C had became more irritating and moulds had started growing.

Bottled refrigerated raw soymilk samples changed in odour and taste on the third day of 
storage. This change was gradual and intensified one week after storage. All these changes confirmed the report of Wilson, (1976), which said that inadequate pasteurization and storage could lead to irritating odour and reduction in the shelf life of soymilk.

The pasteurized and refrigerated soymilk, taste and odour remained unchanged after one week of storage; and when the samples were examined microbiologically, on the sixth day, there was no growth. This indicated that the pasteurization temperature and time were adequate for packaging and storing of soymilk regardless of the production method. The Traditional process $(\mathrm{C})$ gave the highest yield and total solids of soymilk, however, the emulsion was unstable. The yield decrease from nutritionally, soymilk (sample $\mathrm{C}$ ) was the richest except for fat. Nutritive values (except fat) decreased from samples B to A. For soyacake, the nutritive values followed the same pattern as for soymilk. Soyacake in general was nutritionally superior to soymilk for all the production methods.

There was slight colour change in soymilk during pasteurization. Recommended that the time temperature be reduced to about $60^{\circ} \mathrm{C}$ for same 30 min. Light brown coloured soybean should be used for milk production to give the creamy colour resembling that of cows' milk. The green and black vanities produced soymilk of stronger beany odour and impart a yellowish colour to the soymilk.

\section{CONCLUSION}

Soymilk is highly recommended for Nigerians because of the availability of soybean in commercial quantity; soymilk is nutritious except for its low sulphur containing amino acids. It also lacks vitamin D. These nutrients can easily be incorporated in soymilk. It is recommended that soyacake which is very nutritious be processed into other types of food like 'Akara', 'chinchin' or 'moimoi'. These are local foods primarily produced from cowpea flour. On the alternative, soyacake should be dried and used for animal feeds. The cost of cows' milk both powdered and fluid is expensive (170g of fluid milk) sells from N55.00 upwards, that quantity of soymilk will not be up to N20.00. Soybean is everywhere. Members of the public should be taught and encouraged to produce and consume soymilk at home.

Table 1: Percent yield, total solids, and refractive index of soymilk

\begin{tabular}{llcl}
\hline Sample & $* \%$ Yield & *\% Total solids & *Refractive index \\
\hline Illinois (A) & 52.58 & 4.20 & 1.33393 \\
Cornel(B) & 55.17 & 6.83 & 1.3430 \\
Traditional (C) & 57.76 & 7.40 & 1.3442 \\
\hline
\end{tabular}

*Means of three replications 
Table 2: Proximate composition of soybean seeds, soymilk, and soyacake from different production methods.

\begin{tabular}{|c|c|c|c|c|c|c|c|}
\hline Sample & *Moisture & *Protein & *Ash & $*$ Carbc & & $\mathbf{p}$ & \\
\hline & & & & & & Raw Paste & \\
\hline Soybean seed & 8.1038 .9 & 5.0 & 19.0 & $* * \mathrm{~N}$ & $* * \mathrm{~N}$ & $* * \mathrm{~N}$ & - \\
\hline Soymilk (A) & 89.20 & 2.80 & 0.40 & 2.35 & 2.69 & 7.02 & 7.10 \\
\hline (B) & 88.80 & 3.50 & 0.42 & 2.22 & 2.73 & 5.40 & 5.42 \\
\hline (C) & 87.00 & 3.80 & 0.45 & 2.18 & 2.80 & 5.38 & 5.39 \\
\hline Soycake (A) & 30.10 & 6.60 & 0.81 & 4.50 & 7.30 & $\mathrm{~N}$ & $\mathrm{~N}$ \\
\hline (B) & 29.80 & 6.90 & 0.79 & 4.50 & 7.36 & $\mathrm{~N}$ & $\mathrm{~N}$ \\
\hline (C) & 29.40 & 8.00 & 0.79 & 4.38 & 7.51 & $\mathrm{~N}$ & $\mathrm{~N}$ \\
\hline
\end{tabular}

*Mean of three replications

** not determined

Table 3: Total plate count for raw and pasteurized soymilk from different production methods

Sample

* Raw soymilk (Cfu/ml)

*Pasteurized soymilk (Cfu/ml)

$\operatorname{Soymilk}(\mathrm{A})$

$3.10 \times 10^{5}$

No growth

Soymilk (B)

$4.00 \times 10^{5}$

Soymilk (C)

$7.10 \times 10^{5}$

*Mean of three replications

Note: Plate count was also done on the 6th day of storage at $4{ }^{\circ} \mathrm{C}$ for pasteurized sample and the results were as on Table 3 above.

Table 4: Psychrophillic, proteolytic, and coagulase tests on raw and pasteurized soymilk

\begin{tabular}{|c|c|c|c|c|}
\hline \multirow[t]{2}{*}{ Soymilk Sample } & \multicolumn{2}{|c|}{ Psychrophillics } & \multirow{2}{*}{$\begin{array}{l}\text { Proteolytic } \\
\text { Raw }\end{array}$} & \multirow{2}{*}{$\begin{array}{l}\text { Coagulase } \\
\text { Raw }\end{array}$} \\
\hline & Raw & Pasteurized & & \\
\hline Soymilk (A) & No growth & No growth & Coagulation & No clothing \\
\hline Soymilk (B) & “ & “ & “ & “ \\
\hline Soymilk (C) & “ & “ & “ & “ \\
\hline
\end{tabular}


Table 5: Consumer rating (mean score) of soymilk samples from different production methods.

\begin{tabular}{lllcc}
\hline Soymilk Sample & Appearance & \multicolumn{2}{l}{ Flavour After taste } & \multicolumn{2}{c}{ Overall acceptability } \\
\hline Soymilk (A) & $7.55 \pm 1.02$ & $6.10 \pm 1.58$ & $6.30 \pm 1.46$ & $6.70 \pm 1.23$ \\
Soymilk (B) & $6.35 \pm 1.01$ & $4.65 \pm 1.56$ & $5.10 \pm 1.48$ & $5.15 \pm 1.59$ \\
Soymilk(C) & $5.55 \pm 1.24$ & $3.25 \pm 1.55$ & $4.15 \pm 1.62$ & $3.95 \pm 1.36$ \\
\hline
\end{tabular}


Soybean seeds
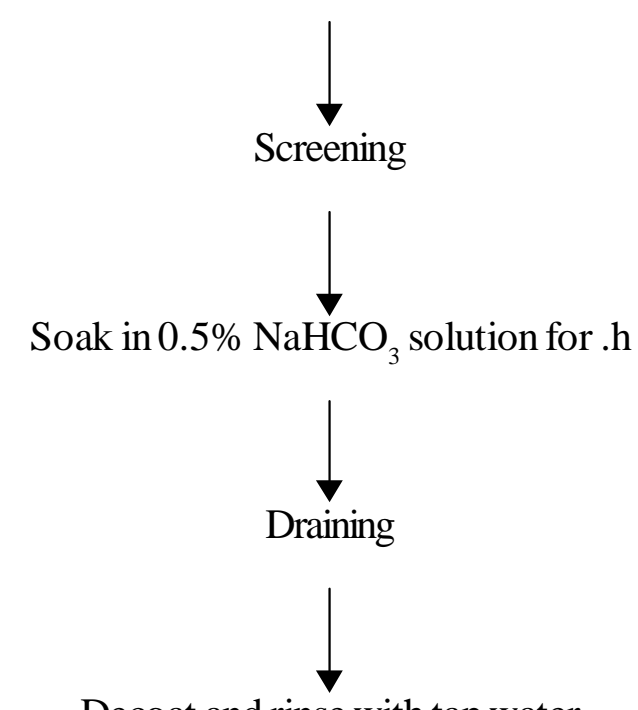

Decoat and rinse with tap water
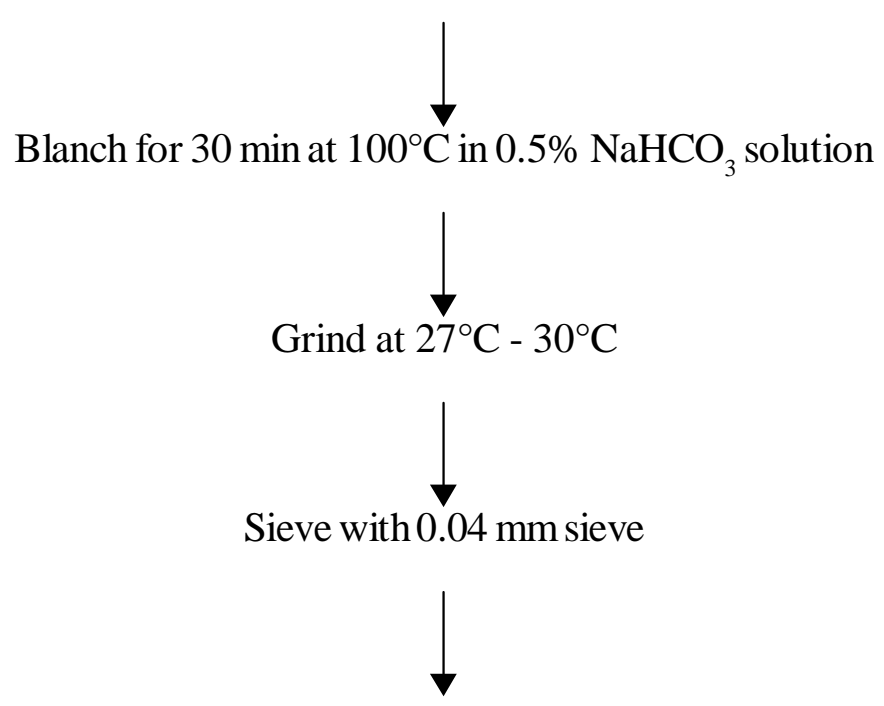

Pasteurize at $68^{\circ} \mathrm{C}$ for $30 \mathrm{~min}$

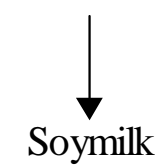

Fig 1: Flow chart for production of soymilk (sample A) 
Soybean seeds
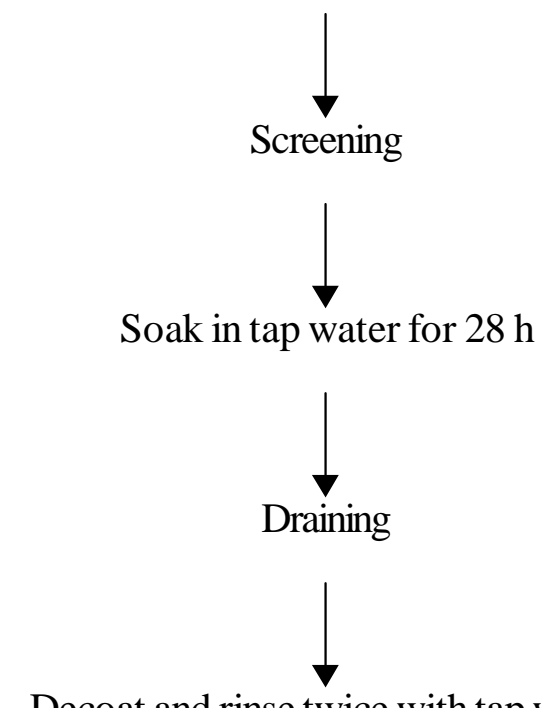

Decoat and rinse twice with tap water

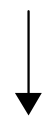

Soak in hot water $\left(100^{\circ} \mathrm{C}\right)$ for $20 \mathrm{sec}$.

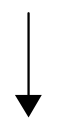

Grind with boiling water

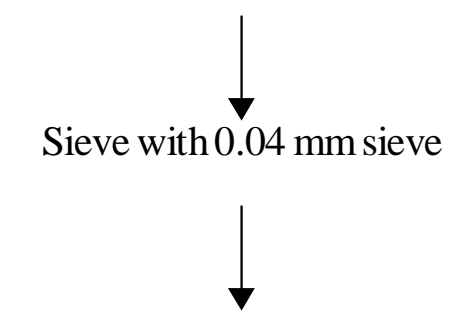

Pasteurize at $68^{\circ} \mathrm{C}$ for $30 \mathrm{~min}$

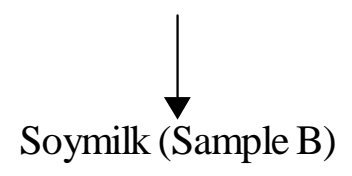

Fig 2: Flow chart for production of soymilk (Cornel Method) Sample B. 
Soybean seeds
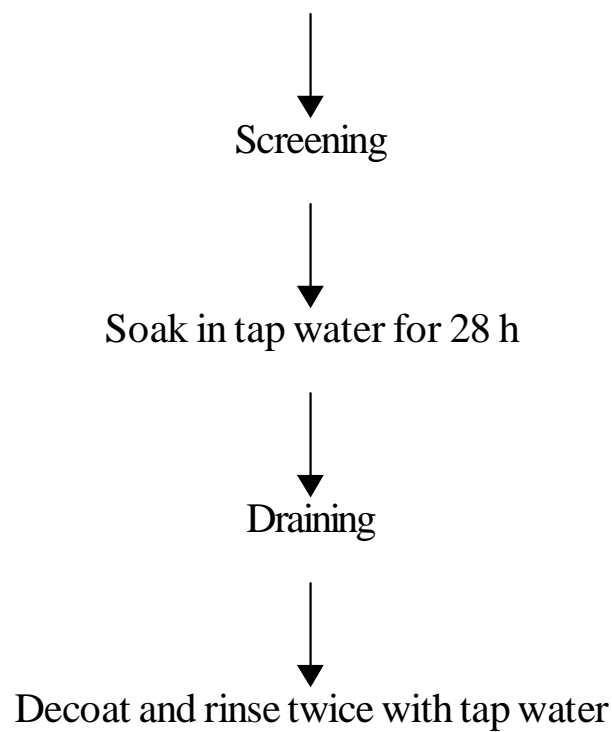

Decoat and rinse twice with tap water

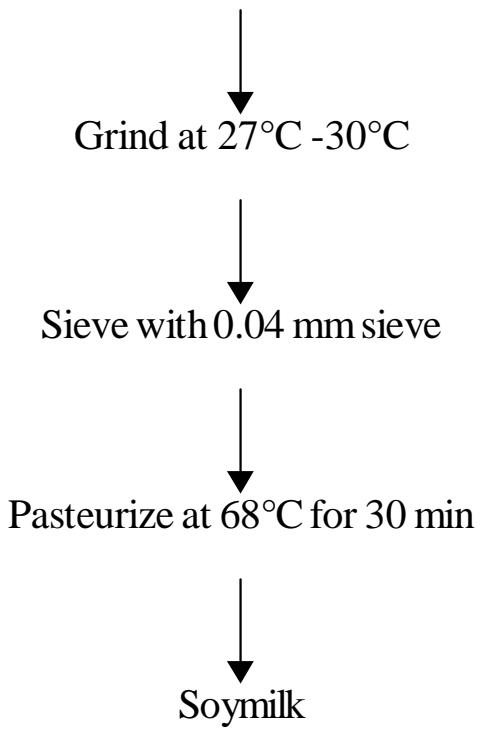

Fig 3: Flow chart for production of soymilk (Traditional Chinese Method) Sample C. 


\section{REFERENCES}

Association of Official Analytical Chemist, (1980). Official methods of Analysis $12^{\text {th }}$ edition. Washington, D.C.

Babajide, A. A., (1985). Production of "SoyWarankasi", Effect of Calcium Treatment and $\mathrm{pH}$ Adjustment on Yield and Quality. Unpublished M. Sc. Thesis, University of Ibadan, Ibadan Nigeria.

Carpenter, P. L., (1977). Microbiology $4^{\text {th }}$ edition, Pp. 395, W. B. Saunder Co., West Washington Square, Philadelphia, USA.

Desrosier, N. W., (1977). Elements of Food Technology. Avi Publishing Co. Inc., Westport, CT, USA.

Johnson, W. K. and Snyder, H. E., (1978). Soymilk, Comparison of Processing Method. Yield and Composition. Journal of Food Science 43: 349.

Joslyn, M. A. (1971). Food Science and Technology, A series of Monographs - Method in Food Analysis, Avi Publishing Co., Westport, CT USA.

Nwanekesi, E. C. (1984). The Effect Of Partial Substitution With Soymilk On the sensory and chemical quality of Warankasi, A white Nigerian Soft Cheese. Unpublished M.Sc. Thesis - University of Ibadan - Nigeria.
Omotoye, O. A. (1984). Production of Soymilk at Economic Cost, Paper presented at the Conference for Food Processors. Durba Hotel Lagos Nigeria.

Person, D. (1981). The Chemical Analysis of Foods, $6^{\text {th }}$ edition. Chemical Publishing Co. Inc., New York.

Shurpalekar, S. R., Charindrasekhara, M. R., Swamination, M., and Subrahamangan,V. (1967). Chemical Composition of Soybean and Nutritive Value of Soybean and Soybean Products. Journal of Food Science 11: 52.

Speck, M. L., (1976). Compendium of methods for the microbiological examination of foods. American Public Health Association, Washington, D. C.

Wang, H. L., Mustakas, G. C., Wolt, W.J., Wang, L. C., and Hesseltine, C.W., and Bagley, E. B. (1978) Soybean as Human Food - Unpublished and Simply Processed. U.S. Department of Agriculture, Utilization Research Report, Number 5.

Wilkens, W.F., Mattick, L. R., and Hand, D, B. (1967). Effects of Processing Method on Oxidative off Flavours of soymilk. Journal of Food Technology, 21:1630.

Wilson, W. J. (1976). Lipozygenase and Flavour of Soybean Protein Products. Journal of Agriculture Food Chemistry, 23:136. 